\title{
ZNAČILNOSTI PRSTI NA POBOČJU TIČNICE NA RAKEKU
}

\author{
Franc Lovrenčak ${ }^{*}$
}

\section{Izvleček}

UDK 911.2:631.47=863(497.4 Rakek)

Globina prsti se na kraškem površju spreminja na kratke razdalje. To so potrdila tudi proučevanja na vzpetini Tičnica na Rakeku v Notranjskem podolju. Tu se globina prsti spreminja od 20 do $110 \mathrm{~cm}$. Vzrok je v tektonski pretrtosti in korozijski razjedenosti. Tam, kjer so nastali globji žepi $v$ dolomitni matični podlagi, je prst globja. V globjih profilih se nahaja rdečkast in glinast Brz horizont. Zgradba profila, lega horizonta in položna pobočja navajajo na sklep, da so glinasti delci netopen ostanek preperavnja matične podlage, ki so ostali na mestu nastanka.

Ključne besede: Globina prsti, matična podlaga, rdeči glinasti Brz horizont, Rakek, Notranjsko podolje.

\section{SOIL CHARACTERISTICS ON THE SLOPE OF TIČNICA AT RAKEK}

\section{Abstract}

Soil depths change in short distances on the karstic surface. This has been also confirmed by an investigation performed on Tičnica hill at Rakek in the Notranjsko valley system where the soil depths vary between 20 and $110 \mathrm{~cm}$. This is due to the tectonically broken and corroded dolomite. On the locations where deeper fissures occurred in dolomite parent material, the soil is deeper. In such deeper profiles, reddish clay Brz horizons occur. From profile morphology, the position of horizon, and gentle slopes a conclusion has been derived, that clay particles are the insoluble residue of parent material weathering, that have remained in the place of origin.

Key words: Soil depth; Parent material; Red clay Brz horizon; Rakek; Notranjsko valley system.

\footnotetext{
* Dr., izr. prof., Oddelek za geografijo, Filozofska fakulteta Univerze v Ljubljani, Aškerčeva 2, SI 1000 Ljubljana, Slovenija
} 


\section{UVOD}

Kraško pokrajino ločujejo od nekraške zlasti reliefne in vodne razmere, saj sta površinska izoblikovanost in voda na zunaj zelo vidna pokrajinska dejavnika. Podrobno proučevanje pa pokaže, da med ločevalne dejavnike poleg reliefa in vode sodi tudi na zunaj manj vidna prst.

Da bi bolje spoznali značilnosti prsti kot sestavnega dela kraške pokrajine, smo jih vzorčno prouevali na pobočju Tičnice na Rakeku. V ospredju je bilo dvoje vprašanj; prvo se je nanašalo na spreminjanje globine prsti na kraškem površju in drugo na avtohtonost ali alohtonost rdečkastega glinastega horizonta $v$ spodnjem delu profila globokih prsti. Ali je glina $v$ tem horizontu ostala na mestu nastanka, kot ostanek preperevanja matične osnove, ali je bila vanj prinešena?

\section{METODE DELA}

Na terenu smo podrobno proučili šest profilov prsti na dveh prerezih skozi odejo prsti. Prvi je bil za staro Osnovno šolo na jugozahodni strani Tičnice v nadmorski višini 470 $\mathrm{m}$ in drugi $v$ novi rakovski soseski na jugovzhodnem pobočju Tičnice $\mathrm{v}$ višini okoli $580 \mathrm{~m}$. V prvem prerezu so bili podrobno proučeni trije profili na razdalji štirih metrov in $v$ drugem tudi trije profili na razdalji sedmih metrov in pol (sliki 1 in 2).

Slika 1: Prerez skozi odejo prsti na Tičnici (1.prerez)

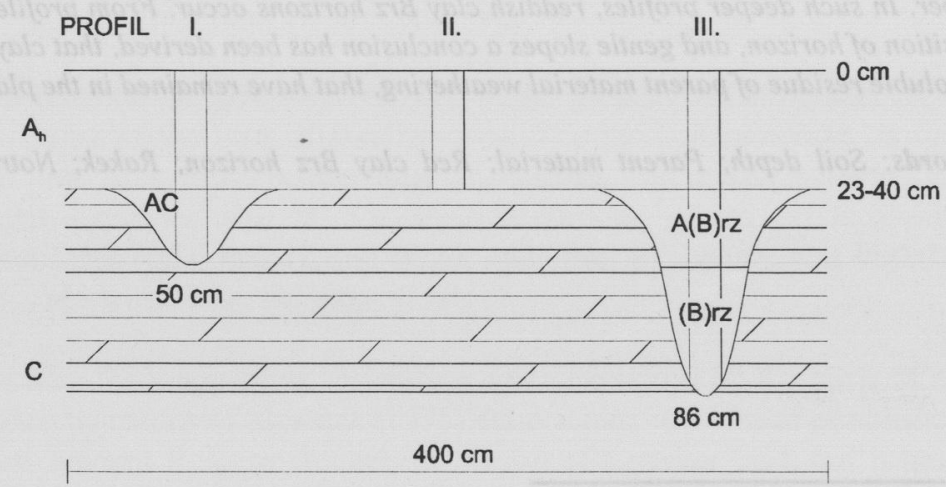


Slika 2: Prerez skozi odejo prsti na Tičnici (2.prerez)

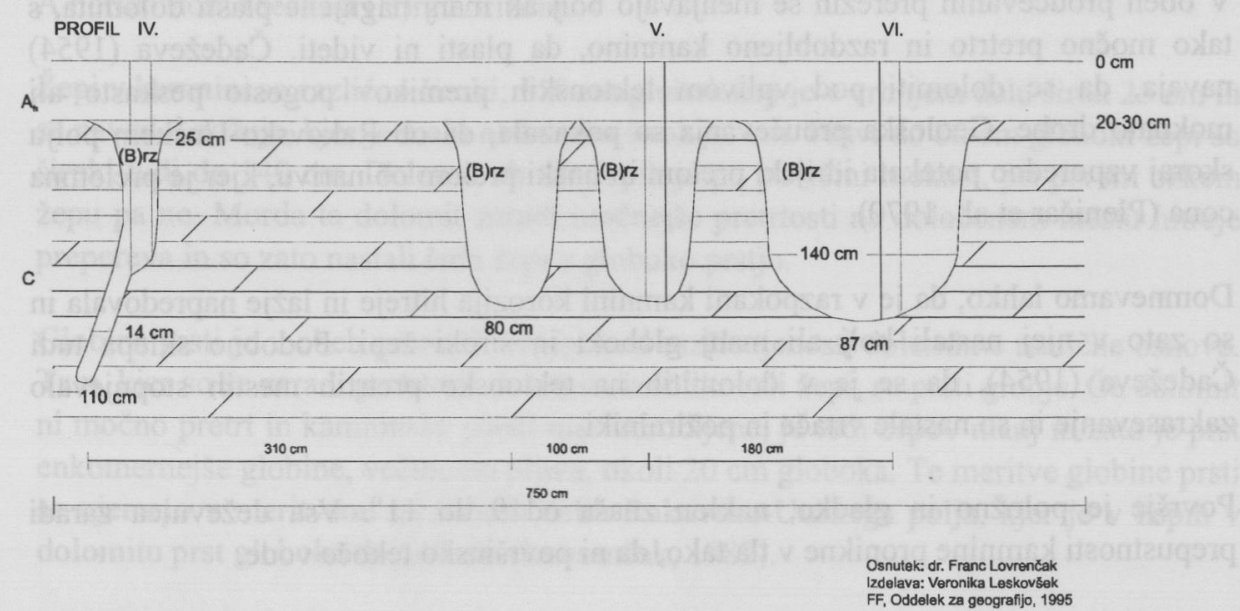

Pri terenskem delu smo izmerili globino prsti, opisali morfologijo profila in iz vseh horizontov vzeli vzorce za laboratorijsko analizo. Barvo smo določili na ovlaženem vzorcu po Munselovem atlasu. Mehanska analiza prsti: vzorci so bili pripravljeni z $0,4 n$ raztopino natrijevega pirofosfata $\left(\mathrm{Na} 10 \mathrm{H}_{2} 0\right)$, posamezne frakcije so bile določene s pipetno metodo, teksturni razredi pa po mednarodnem teksturnem trikotniku. Reakcija prsti je bila izmerjena z digitalnim $\mathrm{pH}$ metrom $(\mathrm{v} \mathrm{KCl})$. Delež prostega $\mathrm{CaCO}_{3}$ smo določili s Scheiblerjevim kalcimetrom. Delež organske snovi pa je bil določen po metodi Walkley-Blacka (Lovrenčak, 1979).

\section{PEDOGENETSKI DEJAVNIKI}

Tičnica je 664 m visoka vzpetina, ki se dviga na vzhodni strani Rakovsko-Unškega polja, nad (90-110 m), suhi dolini podobno reliefno vrzeljo, po kateri je speljana cesta med Rakekom in Cerknico. Nahaja se $v$ nizu vzpetin, ki se dvigajo severno od Rakovsko-Unškega polja (vanj spadata še npr. Orlek in Srnjak). Niz se nadaljuje proti Cerkniškemu polju. Podobne vzpetine se dvigajo tudi vzhodno od Rakovsko-Unškega polja: Kilovec, Lisec, Blaževec in južno od njega: Peščenk, Rakovski grič in Čukov grič.

Tako, kot je ves predel Rakovsko-Unškega polja iz zgornje triasnega dolomita, je tudi Tičnica iz te kamnine. Prevladuje fino kristalasti, sivi, svetlosivi do skoraj beli dolomit (Čadež, 1954). 
$\mathrm{V}$ obeh proučevanih prerezih se menjavajo bolj ali manj nagnjene plasti dolomita, $\mathrm{s}$ tako močno pretrto in razdobljeno kamnino, da plasti ni videti. Čadeževa (1954) navaja, da se dolomiti pod vplivom tektonskih premikov pogosto peskasto ali moknato drobe. Geološka proučevanja so pokazala, da ob Rakovsko-Unškem polju skoraj vzporedno potekata idrijski prelom in unški prelom ob narivu, kjer je prelomna cona (Pleničar et al., 1970).

Domnevamo lahko, da je v razpokani kamnini korozija hitreje in lažje napredovala in so zato $\mathrm{v}$ njej nastali bolj ali manj globoki in široki žepi. Podobno sklepa tudi Čadeževa (1954), da se je v dolomitih na tektonsko pretrtih mestih stopnjevalo zakrasevanje in so nastale vrtače in požiralniki.

Površje je položno in gladko, naklon znaša od 9 do $11^{\circ}$. Vsa deževnica zaradi prepustnosti kamnine pronikne $\mathrm{v}$ tla tako, da ni površinsko tekoče vode.

Podnebje Rakovsko-Unškega polja, na obrobju katerega se nahaja Tičnica je zmerno celinsko, na kar kažejo podatki o temperaturah in padavinah iz najbližje meteorološke postaje, ki je v Planini. Srednja letna temperatura znaša $9,0^{\circ} \mathrm{C}$. Srednja januarska temperatura je $-1,1^{\circ} \mathrm{C}$ in srednja temperatura najtoplejšega meseca (julij) $18,9^{\circ} \mathrm{C}$. Letna količina padavin znaša 1821 mm (Pučnik, 1980).

Temperature, ki jih navaja Habič (1980) za Cerkniško dolino, so nekoliko nižje, saj znaša srednja letna temperatura okrog $8^{\circ} \mathrm{C}$, januarska okrog $-2^{\circ} \mathrm{C}$ in julijska okrog $17^{\circ} \mathrm{C}$. Na leto pa pade povprečno od 1500 do $1700 \mathrm{~mm}$ padavin. Na RakovskoUnškem polju bodo zaradi vmesne nadmorske višine, temperature in padavine verjetno vmes med Planino in Cerkniško dolino.

\section{ZNAČILNOSTI PRSTI}

$\mathrm{Na}$ delih Tičnice, kjer smo merili globino prsti se ta zelo spreminja. V prvem proučevanem prerezu na razdalji štirih metrov sega prst najmanj 33 in največ $86 \mathrm{~cm}$ globoko (slika 1). Profil prsti sestavlja temen A horizont, ki se večinoma nahaja na dolomitni matični osnovi. Tam, kjer so se v dolomitni matični osnovi izoblikovali žepi pa se nahaja pod njim $v$ plitvem žepu prehodni AC horizont in $v$ globokem žepu prehodni $\mathrm{A}(\mathrm{B}) \mathrm{rz}$ in pod njim (B)rz horizont.

Podobno je tudi v drugem prerezu. Tu je na razdalji sedmih metrov in pol prst globoka 20-110 cm (slika 2). Zgradba profila je večinoma enostavna. Svetlo rjavi A horizont 
se nahaja na $\mathrm{C}$ horizontu dolomitne matične osnove. Le $v$ žepih, tukaj so štirje, je pod A horizontom rdečkast (B)rz horizont.

Žepi v kamnini so različno široki; $110 \mathrm{~cm}$ globok žep je v vrhnjem delu širok $25 \mathrm{~cm}$ in se navzdol zožuje, kjer je malo nad dnom širok $14 \mathrm{~cm}$. Plitvi do $86 \mathrm{~cm}$ globoki žepi so široki tudi do $140 \mathrm{~cm}$. Dolomit ob teh žepih je po površini mokast, pri prvem ozkem žepu pa ne. Morda ta dolomit zaradi močnejše pretrtosti na določenem mestu hitreje prepereva in so zato nastali širši žepi z globoko prstjo.

Globina prsti je v obeh prerezih odvisna od razčlenjenosti dolomitne matične osnove. Tam, kjer so se zaradi pretrtosti dolomita izoblikovali žepi, so prsti globje. Če dolomit ni močno pretrt in kamninske plasti niso zdrobljene, je tudi žepov manj in zato je prst enkomernejše globine, večinoma plitva, okoli $20 \mathrm{~cm}$ globoka. Te meritve globine prsti se ujemajo z meritvami na robnih delih Rakovsko-Unškega polja, kjer je v žepih v dolomitu prst globoka do $110 \mathrm{~cm}$ (Lovrenčak, 1989).

$\mathrm{V}$ obeh proučevanih prerezih se $\mathrm{v}$ žepih, kjer je globoka prst, nahaja v spodnjem delu profila, rdečkast, glinast horizont.

V prvem prerezu se ta horizont pojavi v globini $45 \mathrm{~cm}$ in sega do $86 \mathrm{~cm}$. Po teksturi je glinast (45,7\% gline in 39,3\% melja), reakcija je nevtralna in vsebuje le malo prostega kalcijevega karbonata in organske snovi (tabela 1, profil III, (B)rz horizont).

Tabela 1: Nekatere lastnosti prsti na Tičnici

\begin{tabular}{|c|c|c|c|c|c|c|c|c|c|c|c|}
\hline $\begin{array}{l}\text { štev. } \\
\text { prof. }\end{array}$ & $\begin{array}{l}\text { štev. } \\
\text { vzor. }\end{array}$ & $\begin{array}{l}\text { hori- } \\
\text { zont }\end{array}$ & $\begin{array}{c}\text { globina v } \\
\mathrm{cm}\end{array}$ & $\begin{array}{c}\text { grobi } \\
\text { pesek } \\
\% \\
\end{array}$ & $\begin{array}{c}\text { drobni } \\
\text { pesek } \\
\%\end{array}$ & $\begin{array}{c}\text { melj } \\
\% \\
\end{array}$ & $\begin{array}{l}\text { gli- } \\
\text { na } \\
\%\end{array}$ & $\begin{array}{l}\text { teks- } \\
\text { tura }\end{array}$ & $\begin{array}{l}\mathrm{pH} \mathrm{v} \\
\mathrm{KCl}\end{array}$ & $\begin{array}{c}\% \\
\mathrm{CaCO}^{3}\end{array}$ & $\begin{array}{c}\% \\
\text { hu- } \\
\text { musa }\end{array}$ \\
\hline \multirow[t]{2}{*}{$\bar{I}$} & $1 \mathrm{R}$ & & $0-23$ & 21,5 & 17,9 & 38,5 & 22,1 & GI & 7,38 & 27,4 & 8,04 \\
\hline & & $\mathrm{A} / \mathrm{C}$ & $23-50$ & 29,0 & 20,6 & 35.3 & 15,1 & GI & 7,43 & 29,0 & 7,66 \\
\hline II & & & $0-40$ & 20,3 & 15,7 & 43.4 & 20,6 & GI & 7,39 & 21,6 & 8,8 \\
\hline \multirow[t]{3}{*}{ III } & $4 \mathrm{R}$ & & $0-33$ & 29,0 & 2,4 & 46,6 & 22,0 & MGI & 7,41 & 13,8 & 5,74 \\
\hline & & $\mathrm{A}(\mathrm{B}) \mathrm{rz}$ & $33-45$ & 4,4 & 24,0 & 45,3 & 26,3 & MG & 7,21 & 2,4 & 4,98 \\
\hline & & (B)rz & $45-86$ & 1,9 & 13,1 & 39,3 & 45,7 & G & 7,23 & 1,0 & 3,06 \\
\hline \multirow[t]{2}{*}{ IV } & & & $0-20$ & 8,7 & 15,4 & 44,0 & 31,9 & IG & 7,18 & 4,4 & 5,74 \\
\hline & & (B) $r z$ & $20-110$ & 1,3 & 13,6 & 34,9 & 50,2 & G & 7,23 & 2,0 & 2,68 \\
\hline \multirow[t]{2}{*}{ V } & $9 \mathrm{R}$ & & $0-20$ & 16,0 & 18,1 & 37,8 & 28,1 & IG & 7,66 & 22,2 & 6,13 \\
\hline & $10 \mathrm{R}$ & (B) $r z$ & $20-80$ & 1,2 & 6,7 & 19,6 & 72,5 & G & 6,62 & 0,6 & 1,91 \\
\hline \multirow[t]{2}{*}{ VI } & $11 \mathrm{R}$ & & $0-30$ & 5,0 & 17,6 & 41,9 & 35,5 & IG & 6,20 & 0,4 & 4,21 \\
\hline & $12 \mathrm{R}$ & (B) $r z$ & $30-87$ & 0,6 & 2,1 & 25,4 & 72,5 & G & 6,53 & 1,6 & 0,38 \\
\hline
\end{tabular}

Teksturni razredi: GI-glinasta ilovica, MGI-meljasto glinasta ilovica, MG-meljasta glina, G-glina, IGilovnata glina. 
Po reakciji, deležu prostega kalcijevega karbonata in deležu organske snovi (slika 3) so mu podobni glinasti horizonti $\mathrm{v}$ drugem prerezu skozi odejo prsti (tabela 1, profili IV,V,VI, (B)rz horizonti). Opaznejša razlika je le v deležu glinastih delcev, ki je tu precej večji $(50-72 \%$ gline in $19,6-34,9 \%$ melja). Tu se glinast horizont začne $v$ globini $20-30 \mathrm{~cm}$ in sega do $80-110 \mathrm{~cm}$.

Slika 3: Primerjava med nekaterimi lastnostmi prsti na Tičnici in robu Rakovško-Unškega polja

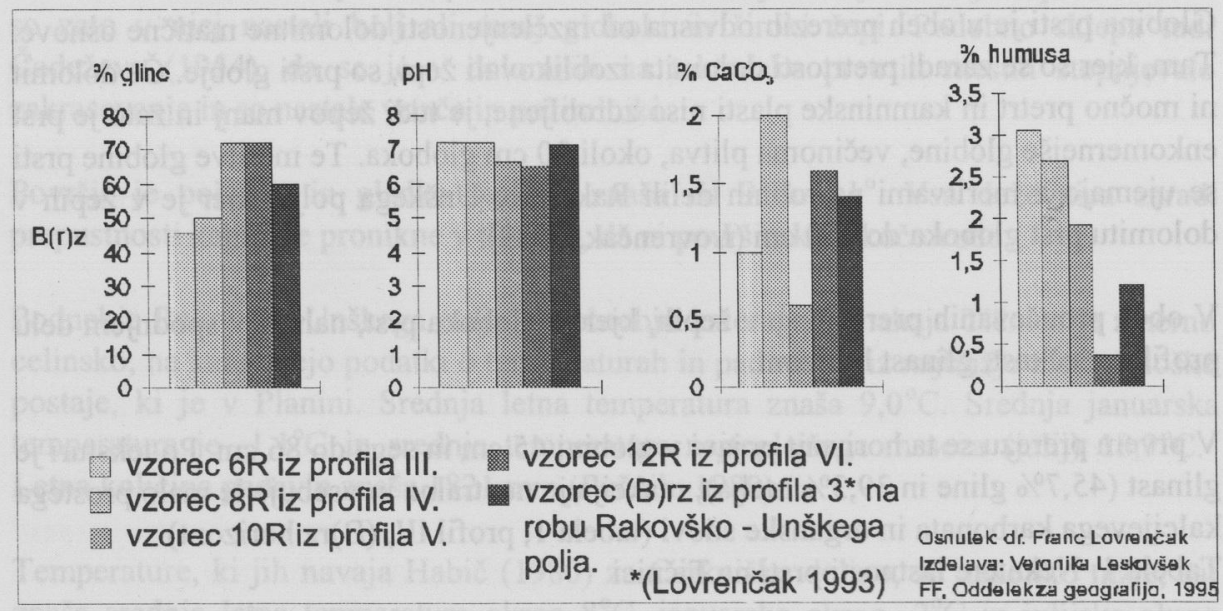

Rdečkast, glinast horizont se nahaja tudi $v$ globokih prsteh na robnih delih in na dnu Rakovsko-Unškega polja. S proučevanimi horizonti bomo primerjali le horizonte na robu tega polja, ker morfologija profila prsti na dnu polja kaže, da gre zelo verjetno pri njih za drugačno genezo.

V horizontih na robu Rakovsko-Unškega polja je podobno visok delež glinastih delcev (55-65\%) kot v prsteh na Tičnici (Lovrenčak, 1989, 1993).

Rdečkast, glinast horizont se nahaja $\mathrm{v}$ prsteh na dolomitu tudi drugod $\mathrm{v}$ Sloveniji (Gregorič, 1969; Stepančič, 1975). Primerjava pokaže, da vsebujejo ti horizonti na Tičnici in robnih delih Rakovsko-Unškega polja podobno visok delež glinastih delcev kot horizonti v prsteh na dolomitu na Dolenjskem (tabela 2). To kaže na podobno genezo prsti na dolomitu v obeh delih Slovenije. 
Tabela 2: Delež glinastih in meljnatih delcev v spodnjih horizontih prsti

\begin{tabular}{lcc} 
& \% gline & \% melja \\
\hline Rdečerjava glina na Tičnici & $45-72 \%$ & $19-30 \%$ \\
$\begin{array}{l}\text { Rdečerjava glina na robu Rakovsko- } \\
\text { Unškega polja }\end{array}$ & $55-65 \%$ & $17-29 \%$ \\
$\begin{array}{l}\text { Rdečerjava glinana dolomitu na } \\
\text { Dolenjskem (Stepančič, 1975) }\end{array}$ & $50-90 \%$ & manj kot 30\% \\
\hline
\end{tabular}

Postavlja se vprašanje nastanka takih prsti in nastanka tega glinastega horizonta. Stepančič (1975) navaja, da so Racz et al. ugotavljali, da sta glina in meljasto glinasta ilovica v prsteh na celinskem krasu Hrvaške istega porekla, in da je slojevitost v prsti posledica postopne sedimentacije in sortiranja ter različne stopnje procesov izpiranja gline.

Proučevanja prsti na triasnem dolomitu pri Grosupljem, ki jih je opravila Gregoričeva (1969) so pokazala, da so rdečkasto rjavi glinasti horizonti avtohtoni in alohtoni. Avtohtoni se nahajajo v prsteh na platojih gričev. Alohtoni pa v prsteh na dnu podolja od Šmarja čez Grosuplje proti Novemu mestu, kamor je bila erozijsko iz višjih leg prenešena rdeče rjava glina.

Proučevanja prsti na robu Rakovsko-Unškega polja (Lovrenčak, 1989) so pokazala, da je tudi tu rdečkast, glinast horizont avtohton. Tudi lastnosti prsti na Tičnici kažejo na tak zaključek.

Že sama morfologija profila prsti, ko se rdečkast, glinast horizont nahaja $v$ bolj ali manj širokih žepih, kaže na to. Ob razpokanem in zdrobljenem dolomitu je korozija hitreje napredovala in zato se je tu bolj kopičil preobražen, netopen ostanek preperevanja dolomita, kot na bolj čvrsti skali.

Prsti se nahajajo tudi na položnem pobočju tako, da je malo verjetno, da bi erozija nanesla glinaste delce $\mathrm{v}$ ponekod ozke in okoli $100 \mathrm{~cm}$ globoke žepe. V profilu prsti tudi ni videti znakov izpiranja gline od zgoraj navzdol.

Na osnovi vsega tega sklepamo, da je tudi v prsti na Tičnici, spodnji rdečkasto rjav, glinast horizont avtohton, da predstavlja netopni ostanek razpadanja dolomita in, da ga lahko označimo kot horizont rezidija - (B)rz. 


\section{LITERATURA}

- Čadež N., 1954: Geologija ozemlja med Planinskim in Cerkniškim poljem. Elaborat: Vodnogospodarske osnove porečja Ljubljanice. Prirodne osnove. Geologija. Ljubljana.

- Gregorič V., 1969: Nastanek tal na triadnih dolomitih. Geologija 12. Ljubljana.

- Habič P., 1981: Geografska podoba Cerkniške doline in njene okolice. Notranjski listi II. Cerknica.

- Lovrenčak F., 1979: Laboratorijske analize prsti. Ljubljana.

- Lovrenčak F., 1989: Pedogeografske razmere na krasu (na dveh primerih). Dela 6, Ljubljana.

- Lovrenčak F., 1995: Pedogeographic characteristics of the Rakovško-Unško polje. Acta carsologica XXIV, Ljubljana.

- Munsell soil color chart, 1992. New York.

- Pleničar et al. 1970: Tolmač za list Postojna L 33-77. Beograd.

- Pučnik J., 1980: Velika knjiga o vremenu. Ljubljana.

- Stepančič D., 1975: Pokarbonatna tla na dolenjskem dolomitnem področju. Zbornik Biotehnične fakultete 25, Ljubljana.

\section{SOIL CHARACTERISTICS ON THE SLOPE OF TIČNICA AT RAKEK}

\section{Summary}

Besides the surface forms and hydrological characteristics, soils are those that also rank among the distinctive karstic factors. To become better acquainted with the characteristics of soil as a natural factor of the karstic landscape, a sample study has been performed, of the soil on the slopes of Tičnica at Rakek, northeast of Postojna. Two questions were of special interest: the first one referred to the variation of soil depths, and the other one, to the origin - autochtone or allocthone - of the reddish clay horizon in the bottom section of soil profiles.

On the terrain, six profiles on two cross-sections of the soil cover were thoroughly investigated. The first one was on the southwestern slope, at the altitude of $470 \mathrm{~m}$ above sea level, and the other one on the southeastern slope, at the altitude of about $580 \mathrm{~m}$. During the field work, soil depths were measured, profile morphologies described, and samples for the lab analyses were taken from all horizons. In the laboratory, the following items were specified: mechanical composition, reaction, the 
percentage of free Calcium and the percentage of organic matter. The colour of a moistened sample was determined according to the Munsel atlas.

Tičnica is a $664 \mathrm{~m}$ high elevation rising on the eastern side of the Rakovško-Unško polje. It is one in a series of elevations which rise above the polje and continue towards the Cerkniško polje. It consists of the upper Triassic dolomite with the prevailing grey to nearly white dolomite which forms the parent material of soil. The bedrock is well fissured and broken owing to tectonic shifts. Our anticipation has been that corrosion is more aggressive in the fissured and broken rocks, which results in more or less deep and wide fissures. The surface is gently sloping and smooth, and the inclination amounts to $9-11^{\circ}$.

The climate is moderate continental which is supported by the data from a nearby meteorological station at Planica. The mean annual temperature amounts to $9^{\circ} \mathrm{C}$, the mean January temperature is $-1.1^{\circ} \mathrm{C}$, and the mean temperature of the warmest month, July, is $18.9^{\circ} \mathrm{C}$. Annual precipitations amount to $1821 \mathrm{~mm}$.

On both slopes where soil depths were measured, the latter vary a lot. On the first slope, within a distance of four meters, the shallowest soil is $33 \mathrm{~cm}$ deep, and the deepest $86 \mathrm{~cm}$. A profile consists of a dark A horizon which mostly occurs on the dolomite parent material. On the spots where fissures occur in the dolomite bedrock, the following situations were found: in shallow fissures, a transitional AC horizon occurs under the A horizon, while in deep fissures, under the A horizon, a transitional A(B)rz horizon occurs, and under the latter, even a (B)rz horizon. Similar situations were found on the other slope where, within a distance of seven meters, the soil is 20$110 \mathrm{~cm}$ deep. Soil profiles consists of a clear brown A horizon atop of a $\mathrm{C}$ horizon of the parent material. Only in the fissures, a reddish (B)rz horizon occurs under the A horizon.

Soil depths on both slopes depend on the dissection intensity of the dolomite parent material. Soils are deeper in the fissures of the broken dolomite. Where the dolomite is not so intenesely broken, fissures are also fewer and, therefore, the soil depths are more even, about $20 \mathrm{~cm}$.

In the fissures of both investigated slopes, the reddish clay horizon occurs in the bottom section of a profile, with $45-72 \%$ of clay particles. On the basis of profile morphology, the position of this horizon in the fissures, and the gentle landforms, a conclusion has been derived that this is an autochtonous horizon. The particles forming this horizon have remained on the place of origin and they represent the changed insoluble residue of the dolomite parent material weathering. 